váltak dominánssá. A 14. század lehülése viszont már az európai , kis jégkorszak" (1550-1860) elôjátéka volt.

A belga kutató által elvégzett éghajlati rekonstrukció, a vizsgálatok interdiszciplináris jellegébôl adódóan, egyszerre klimatológiai és gazdaságtörténeti eredmény. Egyfelốl kétségtelen, hogy az éghajlattörténeti kutatások számára döntô fontosságúak a P. Alexandre által készített idốsorok, hiszen a mûsszeres észleléseket 600 évvel megelōzôen, megbízható éves pontosságú kvantitatív adatokat szolgáltatnak Európa klímájának alakulásáról. Másfelốl az öntörvényũ ökológiai folyamatok hatásainak vizsgálata egy alapvetōen új, természettudományos dimenzióval bővítette a gazdaságtörténeti kutatásokat. A belga történész eredményei így hozzájárulhatnak a tradicionális gazdaság és társadalom mũködési mechanizmusának, zavarainak elemzéséhez és értelmezéséhez. Az ökológiai dimenzióval kibôvuült gazdaságtörténeti elemzések pedig talán közelebb vihetnek a $\mathrm{C}$. Ritter óta nyitott kérdés megválaszolásához, nevezetesen, hogy az európai gazdaság és társadalom mennyi ideig, és milyen mértékben került a környezeti-klimatikus változások hatása alá az iparosodás elổtti korokban. Nem szabad viszont megfeledkezni arról sem, hogy a klímaevolúció nem kizárólag történeti kérdés, hiszen napjaink civilizációja a ,középkori klímaoptimum" idôszakához hasonlóan, a közeljövốben vélhetốen egy jelentôs felmelegedésnek néz elé. Ilyen módon a modern világ hasonló ,,kihíváshelyzetbe" fog kerülni, minı a régi és archaikusabb kultúrák a korábbi ég. hajlatingadozások idején.

A klímatörténeti kutatások szükségszerúer. egy olyan összetett problémacsoporthoz vezetnek, amelyet nem lehet megoldani a diszciplináris válaszfalak tiszteletben tartásával. A történeti-ökológiai kérdések megoldásához egyszerre van szükség klimatológusok, humán geográfusok és gazdaságtörténészek szakismeretére. P. Alexandre könyve elsôsorban e szû̉k szakmai közönség számára készült. Ám a szerzố diszciplináris határokat figyelmen kívül hagyó, problémacentrikus gondolkodásmódja minden hazai kutató számára példa lehet.

Rácz Lajos

\title{
Kisvárosok a középkortól napjainkig
}

J.-P. Poussou - Ph. Loupès (eds.) (1987):

Les petites villes du Moyen Age à nos jours

(Colloque International, Bordeaux, 25-26. octobre 1985.), Paris 511 p.

A várostörténeti kutatások az 1960-as évektốl kezdve példátlanul gyorsan fejlôdtek a világon. Az utóbbi húsz évben hét nagy várostörténeti folyóirat látott napvilágot. ${ }^{\prime} \mathrm{L}$. Mumford korai szintézisét követôen számos összefoglaló munka jelent meg a városok eredetérôl, és fejlốdési pályáiról F. Braudel, P. Bairoch és J. de Vries tollából. Ám ezek a várostörténeti kutatások alig érintették a váro- si piramis alapzatát, a kisvárosokat. Ezér1 P. Clark és J.-P. Poussou javaslatára az eredmények összevetése és a kutatási stratégia meghatározása céljából konferenciára gyúltek össze 1985 októberében a kisvárosokkal foglalkozó nyugat-európai történészek és geográfusok Bordeauxban. A konferencia két napján elhangzott 31 elôadás tematikája idôben átfog. ta a középkor és az újkor évszázadait, térben 
Tér és Társadalom 4. évf. 1990/2. 97-107. p.

pedig lefedte Dél- és Nyugat-Európát. Az elốadássorozat központi kérdése, amelyet egyetlen kutató sem kerülhetett meg, az elemzések tárgyának meghatározása; a kisvárosok fogalmának definiálása volt.

A történeti kutatás számára hosszú idôn keresztül a (kis)városi lét megbízható kritériumának látszott a település erốditett jellege, és a városi cím, illetve az ezzel járó privilégiumok. Ennek a felfogásnak a helyességét látszott igazolni a középkori európai közgondolkodás is, amelyet Werbốczy híres Tripartitumában a következôképpen fogalmazott meg: , ,A város házaknak szükséges falakkal és bástyákkal körülvett sokasága, amely jó és tisztességes megélésre kiváltságolva van." A meghatározás elsố elemét, a középkori városfalak szükségszerũ létét $P$. Clark cáfolta meg, angol példák alapján. A Brit-szigeteken, a kontinentális hatalmaktól izolált helyzetbôl adódóan feleslegessé váltak a települések erôdítései, aminek következtében Angliában gyakorlatilag nincsenek megerổített városok. Brit történészek állítása szerint a középkori és újkori angol gazdaság számára ez a belsố biztonság igen sok haszontalan befektetést tett szükségtelenné.

A középkori jogi terminológiára építố meghatározás, azaz a városi privilégiumok elnyerése sem tekinthetố minden kétséget kizáró támpontnak a kisváros fogalmának definiálásához. A város jogi meghatározásával szemben felmerült kételyeket támasztották alá Ch. Higounet kutatásai is, aki szerint például mikor Eustache de Beaumarchais 1290-ben városi rangra emelte Grenade-sur-Garonne-t, akkor a település a maga 3000 házával valójában már nagyváros volt.

A falvak és a középvárosok között elhelyezkedổ ,átmeneti településcsoport" meghatározását a történeti statisztikával foglalkozó kutatók mennyiségi, demográfiai mutatókkal próbálták elérni. A középkor idejére
Ch. Higounet a város demográfiai küszöbét 150-200 háztartásban (600-800 fổ), míg ugyanezt a kora újkorra $R$. Gascon , ,600 füstben" (2-2500 fố) definiálta. Az újkori francia statisztikusok 2000 , a németek 3500 , míg az angol demográfusok 5000 lakosban határozták meg a városi népességszám alsó határát. B. Chevalier érvelése szerint a mennyjségi-demográfiai szempont a definíció elkészítésénél nem hagyható ugyan figyelmen kívül, de ugyanazon népességszám területenként és koronként igen eltérő minôségû̉ településeket jelenthetett, hiszen a városi lét különbözố elemei nem mutatnak feltétlenül szoros összefüggést a lélekszámmal.

$\mathrm{Az}$ Annales-körhöz tartozó történeti demográfusok a települések demográfiai viselkedése alapján próbálták meghatározni a kisvárosokat. A 19. századot megelốzóen az európai városokban alig-alig fordult elổ, hogy a születések meghaladták a halálozások számát. Ha tehát növekedett a város, akkor az nem saját biológiai erejéból, hanem a környezố falvak emberfeleslegének felszívásával történt. Ezekre a kutatási tapasztalatokra támaszkodva javasolta $\mathrm{C}$. Nières azt az igen érdekes kritériumot, amely szerint a (kis)város férfilakosságának legalább 15-20\%-a a települést övezô 10 km-es zónán kívülrôl kell hogy származzon.

A különbözố diszciplínákat múvelố specialisták egyetértettek abban, hogy a kutatás tárgyának, a kisvárosnak a meghatározását döntổen funkcionális szempontokra kell alapozni. A városi szint definiálására tett javaslatok mindegyikében elôforduló kritérium volt például a ,,székhely" funkció, amely az önigazgató városi tanács mellett jelenthette a királyi és/vagy az egyházi hatalom jelenlétét. Másrészt az európai város elképzelhetetlen volt gazdasági-ipari szerepkör, piac nélkül, ami feltételezte az iparũzốk legalább egyharmados arányát az aktív népességen belül. 
$\mathrm{Ph}$. Guinet véleménye szerint a kiadott iparengedélyek száma, illetve az iparosok aránya kritérium lehet a kisváros és a , ,bourg" (nagyváros) szétválasztásánál, míg az iparengedélyek ára alkalmas a kis- és a középvárosok elkülönítésére. A 19. századtól kezdôdôen Y. Babonaux az ipari tevékenységnél lényegesen fontosabbnak ítélte azt a közvetítố kereskedelmi szerepkört, amelyet a kisvárosok egy-egy bourg vonzásterében láttak el.

J.-B. Laborie a kisvárosokat agglomeráló erố nélküli településekként jellemezte, amelyek nem rendelkeznek az önfenntartó növekedés képességével. Hasonlóan vélekedett C. Nières is, aki szerint a kisvárosok nagyon ,törékeny" települések, hiszen többségük a középkor óta eltünt, és nem fejlôdött nagyvárossá. A túlélő és újjászületố kisvárosok szük köréhez tartozik a $P$. Bairoch által vizsgált Saint-Bertrand-de-Comminges (Felsó-Garonne, Franciaország), amelyet a rómaiak alapítottak i. e. 20-ban Lugdunum Convenarum néven. A városka, gazdaságát a Pireneusok természeti kincseire alapozva, a császárkor első két évszázadában gyorsan fejlôdött. A virágzó települést i. sz. 405-ben a vandál invázió pusztította el. A város második születését Bertrand de l'Isle- Jourdainnek, Comminges püspökének köszönhette, aki Vallis Caprerie néven a 11. században újjáépíttette. Miután V. Kelemen pápa a püspököt 1220-ban szentté avatta, a város zarándoklatok központjává vált. Mivel a település nem tudta újra megszerezni egykori gazdasági funkcióit, és kiépíteni városi ,,erổterét”, az újkorban lassı hanyatlásnak indult. A 18 . század végén vala mivel több mint ezren, 1911-ben 555-en, jelen leg pedig alig 400-an lakját.

A konferenciát lezáró kerekasztal-beszél getésen az összegyứlt kutatók a kisváros fogal mának különbözổ történeti korokban és régi ókban egyaránt helytálló meghatározásá reménytelen vállalkozásnak ítélték. Általáno san elfogadottá vált viszont a $B$. Lepetit álta javasolt kutatási elv, amely szerint a város szint küszöbét döntốen minôségi- funkcioná lis, míg a kis- és a középvárosok közötti határ elsôsorban mennyiségi-demográfiai mutatól alapján célszerú meghatározni. A bordeauxelőadássorozat végén a konferencia egyil szervezốje, J.-P. Poussou a következó módo1 összegezte a tanácskozás legfontosabb tanul ságait: ,,Mindenekelốtt standardizált elemzé si rendszerek segítségével a lehetô legtelje sebb módon fel kell dolgozni az európa kisvárosok történetét. Az így elvégzendố tele püléstörténeti kutatások során pedig el kel vetni a nemzeti nézőpontot, és azt regionáli: szemlélettel kell felcserélni."

\section{Jegyzet}

1 Journal of Urban History (Beverly Hills, 1974), Urbal History Yearbook (Leicester, 1974), Urban History Re wiev/Revue d'histoire urbaine (Winnipeg, 1975), Stori: della Citta (Milano, 1977), Storia urbane (Milano 1977), Urbi, art, histoire et ethnologie des villes (Paris 1979).

Rácz Lajo: 